\title{
ANALISIS SELF CONFIDENCE TERHADAP KEMAMPUAN PEMECAHAN MASALAH MATEMATIS SISWA SMK PADA MATERI BARISAN DAN DERET
}

\author{
Zenal Muh Ramdan ${ }^{1}$, Liana Veralita ${ }^{2}$, Euis Eti Rohaeti ${ }^{3}$, Ratni Purwasih ${ }^{4}$ \\ ${ }_{1,2,3,4}$ Pendidikan Matematika, IKIP Siliwangi \\ E-mail: $\quad$ enallzznotasiband@edukreatif.net ${ }^{1)}$ \\ ratnipurwasih@ikipsiliwangi.ac.id ${ }^{4)}$
}

Received 16 April 2018; Received in revised form 26 June 2018; Accepted 16 July 2018

\begin{abstract}
This study aims to determine the relationship between self confidence on the mathematical problemsolving abilities of students of SMK on the sequence and series material. The method in this research is descriptive qualitative. The place of research conducted at SMK Al-Ibrohimiyah Cianjur academic year 2018/2019 class XII Administration Offices with the number of 17 students. The instruments in this research are self confidence scale questionnaire and math solving ability test. Analysis of data used in this study using SPSS 21.00 with product moment analysis to measure the relationship of self confidence to the ability of problem solving mathematically. Based on the calculation, the result of data analysis shows that there is a correlation coefficient $(r)$ of 0.784 with $p=0,000(p<0.01)$ which means there is a significant positive relationship between self confidence on the ability of problem solving mathematically. This means that self confidence covering the aspects that exist in it can be used as a predictor to measure the ability of problem solving mathematically, the higher the self confidence of students, the students have good problem solving skills, otherwise the lower the students' self confidence, the students has a poor problem solving ability.
\end{abstract}

Keywords: Mathematical Problem Solving, Self Confidence.

\section{PENDAHULUAN}

Pendididkan matematika adalah bagian dari pendidikan nasional dan merupakan salah satu ilmu universal yang mendasari perkembangan teknologi modern yang mempunyai peranan penting dalam berbagai disiplin dan memajukan daya pikir manusia, sehingga pendidikan matematika berperan penting pada setiap individu karena dengan pendidikan matematika setiap individu dapat meningkatkan kemampuan pemecahan masalah, berpikir logis, kritis dan sistematis. Matematika mempunyai potensi besar untuk menjalankan peran strategis dalam menyiapkan sumber daya manusia pada era industrilisasi dan globalisasi yang penuh dengan tantangan. Sehingga jika kemampuan atau potensi yang dimiliki pendidikan matematika mampu memproduk siswa yang berkompotensi dalam matematika dan berhasil menumbuhkan kecakapan, berpikir kritis, logis, inisiatif dan kreatif, terhadap perubahan dan perkembangan zaman. Menurut Sariningsih \& Purwasih (2017) pendidikan matematika dapat mendorong masyarakat untuk selalu maju, terbukti dengan adanya perkembangan teknologi modern. Oleh karena itu, mempelajari dan menguasai matematika dengan baik adalah sebuah keharusan bagi setiap orang. James (Sariningsih \& Purwasih, 2017) mengemukakan bahwa matematika adalah ilmu tentang logika mengenai bentuk, susunan, besaran dan konsep-konsep berhubungan lainnya dengan jumlah yang banyak dan terbagi ke dalam 3 bidang yaitu: aljabar, analisis, dan geometri. Menurut Suherman (Sariningsih \& Purwasih, 2017) Matematika tersusun secara hierarki dari yang mudah sampai yang paling sukar. Sehingga matematika pada hakikatnya merupakan aktifitas mental yang tinggi untuk memahami arti struktur-struktur, hubungan-hubungan, 
simbol-simbol, keabstrakan, yang kemudian menerapkannya dalam situasi nyata. Jadi, belajar matematika adalah aktivitas yang disengaja untuk mendapatkan suatu pengetahuan baik secara langsung maupun tidak langsung melalui lingkungan yang dapat mengakibatkan perubahan tingkah laku.

Salah satu tujuan belajar matematika menurut Peraturan Menteri Pendidikan Nasional Republik Indonesia Nomor 22 Tahun 2006 adalah untuk membekali siswa dengan kemampuan pemecahan masalah yang meliputi kemampuan memahami masalah, merancang model matematika, menyelesaikan model dan menafsirkan solusi yang diperoleh (Depdiknas, 2006). Menjalankan amanat Permendiknas tersebut memerlukan beberapa faktor penting, di antaranya adalah faktor kepercayaan diri siswa agar siswa dapat berpartisipasi aktif, kreatif dan mandiri selama proses pembelajaran. Tidak mudah mewujudkan proses pembelajaran seperti yang diamanatkan permendiknas no. 22 tahun 2006 tersebut. Hal ini terbukti dari hasil TIMSS yang menunjukkan bahwa self-confidence siswa Indonesia masih rendah yaitu dibawah 30 \% (Hapsari, 2011). Hal ini sejalan dengan Azhar (Hapsari, 2011) yang menyatakan rendahnya indeks self confidence siswa ini jika dikaitkan dengan faktor guru disebabkan kegiatan pembelajaran yang dilaksanakan masih didominasi oleh guru dengan metode ceramah dan menuliskan di papan tulis latihan soal untuk siswa yang merupakan warisan turun temurun dan dianggap paling baik. Siswa hanya pasif mendengarkan karena tidak ada instruksi untuk melakukan suatu kegiatan selain mencatat materi dan contoh soal yang dituliskan guru. Akibatnya siswa tidak akan belajar matematika sesuai dengan kebutuhannya. Mereka juga tidak mempunyai kesempatan untuk belajar matematika yang berarti ini menyebabkan kepercayaan diri siswa rendah karena salah satu indikator dari kepercayaan diri adalah rasional dan realistis.

Hannula, Maijah \& Pohkonen (Purwasih, 2015) menyatakan bahwa jika siswa memiliki self confidence yang baik, maka siswa dapat sukses dalam belajar matematika. Oleh karena itu, self confidence mampu mendukung motivasi dan kesuksesan siswa dalam belajar matematika. Siswa akan cenderung memahami, menemukan, dan memperjuangkan masalah matematika yang dihadapinya untuk solusi yang diharapkan. Menurut TIMSS (Purwasih, 2015) menunjukkan bahwa self confidence siswa Indonesia masih rendah dibawah 30\%. Self confidence menurut TIMMS yaitu memiliki matematika yang baik, mampu belajar matematika dengan cepat dan pantang menyerah, menunjukan rasa yakin dengan kemampuan matematika yang dimilikinya, dan mampu berfikir secara realistik. Dengan demikian, dapat disimpulkan bahwa self confidence penting untuk dimiliki oleh siswa. Melalui kerja kelompok atau diskusi, self confidence dapat dikembangkan, di sini siswa dituntut untuk mampu mengeksplorasi dan menemukan sendiri konsep-konsep matematika yang sedang dipelajarinya. Sejalan dengan Hendriana (Sariningsih \& Purwasih 2017) mengatakan bahwa kepercayaan diri akan memperkuat motivasi mencapai keberhasilan, karena semakin tinggi kepercayaan terhadap kemampuan diri sendiri, semakin kuat pula semangat untuk menyelesaikan pekerjaannya.

Kemampuan pemecahan masalah matematis merupakan aspek penting dalam pembelajaran matematika karena proses pemecahan 
matematis merupakan salah satu dasar kemampuan matematis yang harus dikuasai siswa sekolah menengah tingkat atas. Purwasih \& Sariningsih (2017) mengemukakan bahwa pemecahan masalah merupakan tujuan umum dalam pembelajaran matematika, bahkan sebagai jantungnya matematika artinya kemampuan pemecahan masalah merupakan kemampuan dasar dalam belajar matematika. Kemampuan pemecahan masalah merupakan aspek yang penting, karena dapat menjadikan siswa terdorong untuk membuat keputusan terbaik jika menghadapi masalah dalam kehidupannya. Menurut Mayer (Kirkley dalam Kartika, 2017) bahwa pemecahan masalah merupakan suatu proses banyak langkah dengan si pemecah masalah harus menemukan hubungan antara pengalaman (skema) masa lalunya dengan masalah yang sekarang dihadapinya dan kemudian bertindak untuk menyelesaikannya.

$$
\text { Kemampuan pemecahan }
$$

masalah matematis yang baik akan berpengaruh terhadap hasil belajar matematika untuk menjadi lebih baik dan juga merupakan tujuan umum pengajaran matematika. Menurut Sumarmo (Kurniawan, 2016), indikator pemecahan masalah dapat dirangkum secara lebih rinci sebagai berikut: (1) kemampuan memahami masalah, (2) kemampuan merencanakan pemecahan masalah, (3) kemampuan melakukan pengerjaan atau perhitungan, 4) Menjelaskan atau menginterpretasikan hasil sesuai permasalahan awal. dan 5) Menggunakan matematika secara bermakna.

Berdasarkan beberapa penelitian mengemukakan bahwa kemampuan pemecahan masalah matematis merupakan salah satu keterampilan yang harus dikuasai siswa, namun kenyataan dilapangan memperlihatkan bahwa keterampilan pemecahan masalah belum dilatih secara maksimal. Wahyudin (1999) menemukan bahwa guru matematika pada umumnya mengajar dengan metode ceramah dan ekspositori. Sebagian besar siswa hanya memperoleh informasi dan penjelasan yang diberikan oleh guru. Siswa sangat jarang mengajukan pertanyaan, hanya menerima saja apa yang disampaikan oleh guru sehingga siswa tidak mendapatkan kesempatan untuk menemukan dan membangun pengetahuan mereka sendiri. Sejalan dengan Sumarmo (Rohaeti, 2008) juga menyatakan bahwa keterampilan siswa SMA maupun SMP di Jawa Barat dalam menyelesaikan masalah matematis masih tergolong rendah. Kemampuan pemecahan masalah matematis yang baik akan berpengaruh kepada hasil belajar matematika untuk menjadi lebih baik dan juga merupakan tujuan umum pengajaran matematika, karena kemampuan pemecahan masalah matematis dapat membantu dalam memecahkan persoalan baik dalam pelajaran khusunya pada materi barisan dan deret maupun dalam kehidupan sehari-hari. Kurangnya kemampuan pemecahan masalah matematis siswa akan menyebabkan proses belajar mengajar matematika itu tidak mencapai tujuan hasil belajar yang diharapkan. Sesuai dengan uraian di atas, hal-hal yang ingin diuraikan dalam penelitian ini yaitu apakah siswa yang memiliki kemampuan pemecahan masalah yang tinggi memiliki self confidence yang baik atau malah sebaliknya. Tujuan dari penelitian ini untuk mengetahui hubungan antara self confidence terhadap kemampuan pemecahan masalah matematis siswa SMK pada materi barisan dan deret. Tujuan dari penelitian ini untuk mengetahui hubungan antara self confidence terhadap kemampuan 
pemecahan masalah matematis siswa SMK pada materi barisan dan deret.

\section{METODE PENELITIAN}

Tempat penelitian dilaksanakan di SMK Al-Ibrohimiyah Cianjur, semester ganjil tahun 2017-2018. Penelitian ini tergolong dalam penelitian deskriptif kualitatif yang berupaya untuk mendeskripsikan analisis self confidence terhadap kemampuan pemecahan masalah matematis siswa SMK pada materi barisan dan deret. Metode yang digunakan pada penelitian ini adalah kualitatif deskriptif. Jenis ini dipilih karena bertujuan untuk menggambarkan self confidence siswa dalam menyelesaikan soal-soal pemecahan masalah matematis siswa secara mandiri. Subjek dalam penelitian ini adalah XII Administrasi Perkantoran. Subjek dipilih secara purposive dengan meminta pendapat guru kelas yang memahami kondisi kognitif dan afektif siswa.

Tahap penelitian terbagi menjadi tiga, yaitu perencanaan, pelaksanan dan pelaporan. Pada tahap perencanaan peneliti menyiapkan perangkat instrumen self confidence meliputi kisikisi angket, bobot angket, dan penskoran perangkat instrumen pemecahan masalah matematis meliputi kisi-kisi soal, lembar jawaban dan penskoran. Selanjutnya pada tahap pelaksanaan siswa diberi tes penalaran matematis, setelah itu siswa mengisi angket kemandirian belajar. Pada tahap laporan, peneliti mengolah data yang diperoleh selama penelitian berlangsung dan menyusun laporan.

Instrumen yang di gunakan dalam penelitian ini adalah angket skala self confidence yang terdiri dari 32 pernyataan dan disusun berdasarkan indikator-indikator variabel yang merupakan ciri-ciri prilaku yang hendak diteliti dan untuk tes kemampuan pemecahan masalah matematis disusun dalam bentuk essay terdiri dari 5 soal pemecahan masalah yang disusun untuk mengetahui kemampuan pemecahan masalah matematis siswa, Sebelum tes ini diberikan, instrumen ini terlebih dahulu dikonsultasikan dengan dosen pembimbing agar memiliki validitas isi, sedangkan agar memiliki validitas empiris maka instrumen tersbut diujicobakan untuk mengetahui validitas, reliablitas, daya pembeda dan indeks kesukaran.

Teknik pengambilan data untuk self confidence dilakukan dengan cara menyebar angket. Bentuk skala yang digunakan dalam penelitian adalah skala model Likert, dengan empat alternatif pilihan jawaban yang terdiri dari pernyataan positif dan pernyataan negatif yang dimulai dari SS (Sering sekali), SR (Sering), JR (Jarang) JS (Jarang sekali). Pernyataan positif terdiri dari pertanyaan-pertanyaan yang bersifat positif atau mendukung objek sikap. Sedangkan pernyataan negatif terdiri dari pertanyaan-pertanyaan negatif atau tidak mendukung objek sikap. Format skoring skala self confidence matematik disajikan pada Tabel 1 berikut:

Tabel 1. Format Skoring Skala self confidence Matematis

\begin{tabular}{ccc}
\hline Pilihan Jawaban & Pernyataan Positif & Pernyataan Negatif \\
\hline SS & 4 & 1 \\
SR & 3 & 2 \\
JR & 2 & 3 \\
JS & 1 & 4 \\
\hline
\end{tabular}




\section{HASIL PENELITIAN DAN PEMBAHASAN}

Metode penelitian ini adalah deskriptif kualititatif. Penelitian ini dilaksanakan pada siswa kelas XII Administrasi Perkantoran semester 1 di SMK Al-Ibrohimiyah Cianjur tahun pelajaran 2017-2018. Jumlah siswa di kelas tersebut adalah 17 orang. Peneliti memberikan 5 butir soal pemecahan masalah dengan materi barisan dan deret. Setelah selesai, siswa diberikan angket untuk mengukur self confidence matematis. Tes dilakukan selama 90 menit.

\begin{abstract}
Data tentang self confidence diperoleh melalui angket yang diberikan, selanjutnya data diolah dan dianalisis berdasarkan rubrik penilaian dan Analisis data yang dipergunakan dalam penelitian ini menggunakan bantuan SPSS 21.00 dengan analisis product moment untuk mengukur hubungan antara kepercayaan diri dengan kemampuan pemecahan masalah matematis. Skor awal untuk self confidence dan kemampuan pemecahan masalah matematis dapat dilihat pada tabel dibawah ini.
\end{abstract}

Tabel 2. Hasil Skor Self Confidence dan Pemecahan Masalah Matematis Siswa

\begin{tabular}{clcccccc}
\hline \multirow{2}{*}{$\begin{array}{c}\text { Nom } \\
\text { or }\end{array}$} & Nama Siswa & \multicolumn{3}{c}{ Self Confidence } & \multicolumn{3}{c}{$\begin{array}{c}\text { Pemecahan Masalah } \\
\text { Matematis }\end{array}$} \\
\cline { 3 - 8 } & & Skor Ideal & $\begin{array}{c}\text { Jumlah } \\
\text { Skor }\end{array}$ & $\begin{array}{c}\text { Rata- } \\
\text { rata }\end{array}$ & $\begin{array}{c}\text { Skor } \\
\text { Ideal }\end{array}$ & $\begin{array}{c}\text { Jumlah } \\
\text { Skor }\end{array}$ & $\begin{array}{c}\text { Rata- } \\
\text { rata }\end{array}$ \\
\hline 1 & Ahmad Rosidin & 128 & 94 & 2,9 & 20 & 15 & 3 \\
2 & Asri Prunamasari & 128 & 96 & 3 & 20 & 15 & 3 \\
3 & Dea Tripiani & 128 & 91 & 2,8 & 20 & 10 & 2 \\
4 & Deuis Hopipah & 128 & 95 & 3 & 20 & 18 & 3,6 \\
5 & Elis Siti Solihat & 128 & 115 & 3,6 & 20 & 20 & 4 \\
6 & Fitri Maulani & 128 & 103 & 3,2 & 20 & 16 & 3,2 \\
7 & Lulu Komala & 128 & 107 & 3,3 & 20 & 18 & 3,6 \\
8 & Mirawati & 128 & 106 & 3,3 & 20 & 16 & 3,2 \\
9 & Nurhayati & 128 & 93 & 2,9 & 20 & 14 & 2,8 \\
10 & Ridah Faridah & 128 & 95 & 3 & 20 & 14 & 2,8 \\
11 & Seni Azizah & 128 & 93 & 2,9 & 20 & 14 & 2,8 \\
12 & Siti Sopiah & 128 & 94 & 2,9 & 20 & 13 & 2,6 \\
13 & Ucu Kusmiati & 128 & 93 & 2,9 & 20 & 12 & 2,4 \\
14 & Ucu Nadia Ulhaq & 128 & 102 & 3,2 & 20 & 17 & 3,4 \\
15 & Upi Upiyah & 128 & 92 & 2,9 & 20 & 10 & 2 \\
16 & Yuda yudistira & 128 & 93 & 2,9 & 20 & 15 & 3 \\
17 & Yuni Rushayanti & 128 & 90 & 3 & 20 & 8 & 1,6 \\
\hline
\end{tabular}

Dari pengolahan hasil perhitungan skor awal menunjukan bahwa siswa yang mempunyai self confidence tinggi mempunyai kemampuan pemecahan masalah yang baik, begitu juga sebaliknya siswa yang mempunyai self confidence yang rendah mempunyai kemampuan pemecahan masalah yang kurang baik hal ini menunjukan bahwa self confidence 
memiliki pengaruh terhadap dengan menggunakan software SPSS kemampuan pemecahan masalah versi 21.00 seperti yang tersaji pada matematis, hal ini dibuktikan dengan hasil analisis regresi yang dilakukan tabel dibawah ini.

Tabel 3. Analisis Regresi

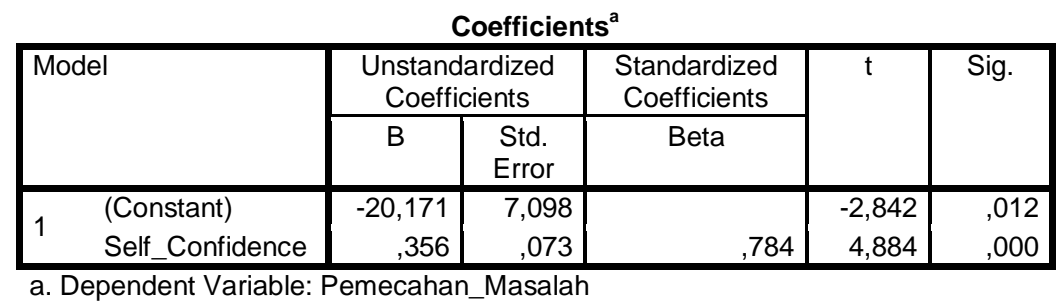

Berdasarkan hasil analisis regresi pada tabel 3 menunjukan bahwa nilai $\mathrm{t}$ hitung untuk self confidence sebesar 4,884 dengan nilai signifikansi $0,000<0,05$ maka ada pengaruh yang signifikan self confidence terhadap kemampuan pemecahan masalah. Analisis data yang digunakan untuk mengukur hubungan antara kepercayaan diri dengan kemampuan pemecahan masalah matematis dalam penelitian ini adalah korelasi produt moment dari Pearson yang tersaji pada tabel dibawah ini.

Tabel 4. Korelasi Antara Self Confidence dan Pemecahan Masalah Matematis Siswa

\begin{tabular}{|c|c|c|c|}
\hline & & Self_Confidence & $\begin{array}{c}\text { Kemampuan_Pemecahan_ } \\
\text { Masalah_Matematis }\end{array}$ \\
\hline \multirow{4}{*}{ Self_Confidence } & Pearson Correlation & 1 &, $784^{* *}$ \\
\hline & Sig. (2-tailed) & & 000 \\
\hline & $\mathrm{N}$ & 17 & 17 \\
\hline & Pearson Correlation &, $784^{* *}$ & 1 \\
\hline \multirow{2}{*}{$\begin{array}{l}\text { Kemampuan_Pemecahan_Mas } \\
\text { alah_Matematis }\end{array}$} & Sig. (2-tailed) &, 000 & \\
\hline & $\mathrm{N}$ & 17 & 17 \\
\hline
\end{tabular}

Hasil analisis data menunjukkan ada koefisien korelasi (r) sebesar 0,784 dengan $\mathrm{p}=0,000(\mathrm{p}<0,01)$, yang artinya terdapat hubungan positif yang sangat signifikan antara self confidence dengan kemampuan pemecahan masalah. Semakin tinggi self confidence siswa, maka siswa memiliki kemampuan pemecahan masalah yang baik, sebaliknya semakin rendah self confidence siswa, maka siswa memiliki kemampuan pemecahan masalah yang kurang baik. Hal ini berarti variabel kepercayaan diri mencakup aspek-aspek yang ada di dalamnya dapat dijadikan sebagai prediktor untuk mengukur kemampuan pemecahan masalah matematis. Tidak hanya untuk kemampuan pemecahan masalah saja self confidence mempunyai hubungan yang positif tetapi untuk kemampuan yang lainnya juga, hal ini sesuai dengan penelitian yang dilakukan oleh Purwasih (2015) yang mengungkapkan bahwa self confidence dan kemampuan pemahaman matematis mempunyai hubungan yang positif.

Salah satu hasil tes kemampuan pemecahan masalah matematis siswa yang mempunyai kemampuan self confidence yang tinggi pada materi 
barisan dan deret terlihat pada gambar

1.

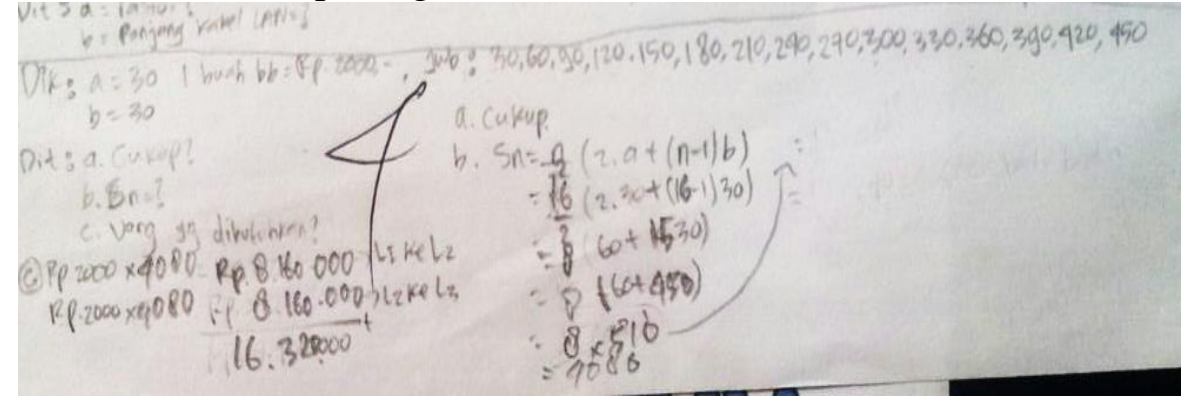

Gambar 1. Jawaban Siswa Soal Nomor 5

Pada Gambar 1, salah satu jawaban dari siswa dengan kemampuan self confidence yang tinggi mengenai soal barisan dan deret. Terlihat pada gambar, siswa tersebut mampu menyelesaikan soal kemampauan pemecahan masalah dengan baik, siswa mampu memahami permaslahan yang disajikan pada soal dengan menuliskan apa yang diketahui dan yang ditanyakan pada soal tersebut, siswa mampu melakukan langkah penyelesaian masalah yang harus dilakukan untuk menjawab soal, hal tersebut dikarenakan : 1) siswa percaya diri dengan kemampuan sendiri dan memahami materi barisan dan deret dengan baik; 2) siswa mampu bertindak mandiri dalam mengambil keputusan untuk menjawab soal tersebut tanpa bantuan orang lain; 3) siswa berani menghadapi tantangan dalam menyelesaikan soal matematika dalam bentuk apapun. Untuk siswa dengan kemampuan self confidence yang rendah bisa dilihat pada Gambar 2:

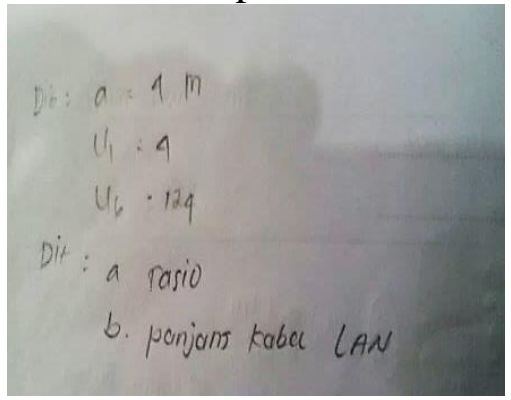

Gambar 2. Jawaban Siswa Soal No 4.
Terlihat pada gambar 2. Siswa belum dapat menguasai dengan baik kemampuan pemecahan masalah, pada gambar tersebut terlihat siswa hanya mampu memahami masalah saja, siswa tidak bisa merencanakan pemecahan masalah, melakukan dan melakukan perhitungan untuk meneyelesaikan permasalahn pada soal tersebut. Hal ini terjadi dikarenakan: 1) siswa tidak percaya pada kemampuan diri sendiri dan tidak memahami materi barisan dan deret dengan baik; 2) siswa tidak bisa bertindak sendiri dalam mengambil keputusan untuk menyelesaikan soal tersebut, dan tidak bisa untuk merencanakan pemecahan serta melakukan perhitungan dari soal tersebut; 3) siswa merasa sulit menyelesaikan soal yang tidak biasa atau rutin; 4) Kesalahan tidak dapat menentukan rumus yang harus digunakan untuk menyelesaikan masalah. Hal ini sejalan dengan penelitian Farida (2015) bawah penyebab kesalahan dalam menuliskan rumus adalah karena lupa rumus apa yang akan digunakan dalam menyelesaikan masalah. Siswa cenderung hanya menghafal rumus yang diberikan oleh guru sehingga siswa cepat lupa dengan rumus yang sudah diberikan.

Berdasarkan hasil pengolahan data dan analisis dapat di simpulkan bahwa self confidence dan kemampuan pemecahan masalah memiliki hubungan 
yang erat. Hubungan tersebut sifatnya saling mendukung dan saling menguntungkan satu sama lainnya. Hal ini menunjukan bahwa kemampuan self confidence siswa mendukung terhadap respon siswa dalam menghadapi permasalahan matematika. Siswa diperlukan latihan atau drill soal-soal yang menuntut berpikir solusi dalam bentuk pemecahan masalah.

\section{KESIMPULAN DAN SARAN}

Berdasarkan hasil analisis data dan pembahasan yang diuraikan, maka dapat ditarik kesimpulan bahwa terdapat hubungan positif yang sangat signifikan antara self confidence dengan kemampuan pemecahan masalah yang ditunjukan dengan koefisien korelasi (r) sebesar 0,784 dengan $\mathrm{p}=0,000(\mathrm{p}<$ $0,01)$. Hal ini berarti self confidence yang mencakup aspek-aspek yang ada di dalamnya dapat dijadikan sebagai prediktor untuk mengukur kemampuan pemecahan masalah matematis, semakin tinggi self confidence siswa, maka siswa memiliki kemampuan pemecahan masalah yang baik, sebaliknya semakin rendah kepercayaan diri siswa, maka akan siswa memiliki kemampuan pemecahan masalah yang kurang baik.

Berdasarkan kesimpulan yang telah dipaparkan di atas maka peneliti memaparkan beberapa saran diantaranya, 1) Bagis siswa, hendaknya siswa dapat memupuk dan mengembangkan tingkat kepercayaan diri (self confidence) yang dimiliki, selalau berpikiran positif terhadap diri sendiri bahwa kita mampu dan bisa untuk menyelesaikan segala persoalan dalam pelajaran matematika, 2) Bagi guru, diharapakan dapat mencermati tingkah laku siswa sehingga dapat mengetahui cara-cara yang efektif dalam memupuk dan mengembangkan tingkat kepercayaan diri (self confidence), 3) Bagi peneliti selanjutnya perlu mempertimbangkan faktor-faktor lain yang dapat mempengaruhi kemampuan pemecahan masalah siswa, baik faktor internal, eksternal maupun faktor pendekatan pembelajaran.

\section{DAFTAR PUSTAKA}

Farida, N. (2015). Analisis Kesalahan Siswa SMP Kelas VIII dalam Menyelesaikan Masalah Soal Cerita Matematika. Aksioma Jurnal Pendidikan Matematika FKIP Univ. Muhammadiyah Metro, 4(2), 42-52.

Hapsari, M. J., (2011). Upaya Meningkatkan Self-Confidence Siswa Dalam Pembelajaran Matematika Melalui Model Inkuiri Terbimbing. Seminar Nasional Matematika dan Pendidikan Matematika UNY.

Kartika, H. (2017). Meningkatkan Kemampuan Pemecahan Masalah Matematis Dan Self-Concept Calon Guru Di Kabupaten Karawang Melalui Pendekatan Open-Ended. Aksioma

Jurnal Pendidikan Matematika FKIP Univ. Muhammadiyah Metro, 6(2), 198-204.

Kurniawan, M. (2016) Penerapan Pendekatan Problem Solving Untuk Meningkatkan Kemampuan Pemecahan Masalah Matematis Siswa SMP. Publikasi STKIP Siliwangi Bandung, Jurnal Hasil Penelitian.

Peraturan Menteri Pendidikan Nasional Republik Indonesia Nomor 22. Jakarta: Pusat Kurikulum, Badan Penelitian dan Pengembangan Depdiknas.

\section{8 | AKSIOMA}


ISSN 2089-8703 (Print) Vol. 7, No. 2 (2018) 171-179

ISSN 2442-5419 (Online)

Purwasih, R. (2015). Meningkatan Kemampuan Pemahaman Matematis dan Self Confidence Siswa MTs di Kota Cimahi melalui Model Pembelajaran Inkuiri Terbimbing. Didaktik, 9 (1), 16-25.

Rohaeti E, E. (2008). Pembelajaran Matematika dengan Menggunakan Metode IMPROVE untuk Meningkatkan Pemahaman dan Kemampuan Komunikasi Matematika Siswa SLTP. (Disertasi) Sekolah Pascasarjana, UPI: Educationist.
Sariningsih, R., \& Purwasih, R. (2017). Pembelajaran Based Learning untuk

Meningkatkan Kemampuan Pemecahan Masalah dan Self Efficacy Mahasiswa Calon Guru. Jurnal JNPM (Jurnal Nasional Pendidikan Matematika), 4(1),163-177.

Wahyudin. (1999). Kemampuan Guru Matematika, Calon Guru Matematika dan Siswa dalam Mata Pelajaran Matematika. Disertasi pada PPS UPI: tidak diterbitkan. 